\title{
Risk Assessment of Using Entonox for the Relief of Labor Pain: A Healthcare Failure Modes and Effects Analysis Approach
}

Tahereh Fathi Najafi ${ }^{1}$, Narjes Bahri ${ }^{2}$, Hosein Ebrahimipour ${ }^{3}$, Ali Vafaee Najar ${ }^{4}$, Yasamin Molavi Taleghani ${ }^{5}$

${ }^{1}$ Ph.D. Student of Reproductive and Sexual Health, Department of Midwifery, Islamic Azad University, Mashhad Branch, Mashhad, Iran

${ }^{2}$ Ph.D. Student of Reproductive Health, Department of Midwifery, faculty of Nursing and Midwifery, Gonabad University of Medical Sciences, Gonabad, Iran

${ }^{3} \mathrm{Ph}$.D. of Health services Management, Associate Professor, Health Sciences Research Center, Faculty of Health, Mashhad University of Medical Sciences, Mashhad, Iran

${ }^{4} \mathrm{Ph} . \mathrm{D}$. of Health Services Management, Associate Professor, Department of Health and Management, Faculty of Health, Mashhad University of Medical Sciences, Mashhad, Iran

${ }^{5}$ Ph.D. Student of Health Services Administration, Health Management and Economics Research Center, Department of Management and Medical Information, Isfahan University of Medical Sciences, Isfahan, Iran

\section{Type of article: Original}

\begin{abstract}
Introduction: In order to prevent medical errors, it is important to know why they occur and to identify their causes. Healthcare failure modes and effects analysis (HFMEA) is a type of qualitative descriptive that is used to evaluate the risk. The aim of this study was to assess the risks of using Entonox for labor pain by HFMEA.

Methods: A mixed-methods design (qualitative action research and quantitative cross-sectional research) was used. The modes and effects of failures in the process of using Entonox were detected and analyzed during 20132014 at Hefdahe Shahrivar Hospital, Mashhad, Iran. Overall, 52 failure modes were identified, with 25 being recognized as high-risk modes.

Results: The results revealed that $48.5 \%$ of these errors fall into the care process type, $22.05 \%$ belong to the communicative type, $19.1 \%$ fall into the administrative type, and $10.2 \%$ are of the knowledge and skills type. Strategies were presented in the forms of acceptance (3.2\%), control (90.3\%), and elimination (6.4\%).

Conclusion: The following actions are suggested for improving the process of using Entonox: Close supervision by the midwife, precise recording of all the stages of the process in the woman's medical record, the necessity of the presence of the anesthesiologist at the woman's bedside during labor, confirming the indications for use of Entonox, and close monitoring to ensure the safety of the gas cylinder guards.

Keywords: risk assessment, Entonox, labor pain, healthcare failure modes and effects analysis
\end{abstract}

\section{Introduction}

In recent decades, the quality of health and safety care of patients has become a very important objective in improving healthcare systems (1). The report called "To Err is Human: Building a Safer Health System," which was published in 1999, showed that medical errors are very common and have detrimental effects on patients (2). The Institute of Medicine (IOM) in the USA also reported in 1999 that, every year, 44,000 to 98,000 patients die due to treatment errors. This figure, which is in fact higher than the mortality rate caused by car accidents, breast cancer, and AIDS, provoked serious concerns about medical errors. Following the publication of this report, which was a call for the improvement of health systems, serious steps were launched to reduce medical errors (1). In spite of this, the results of the assessment of medical errors 10 years after the publication of the above-mentioned report indicated that the safety condition of patients, rather than improving, had actually worsened. For example, one in every seven hospitalized patients experiences one or more adverse outcomes, and, every year, thousands of patients have blood

\section{Corresponding author:}

Narjes Bahri, Department of Midwifery, faculty of Nursing and Midwifery, Gonabad University of Medical Sciences, Gonabad, Iran. Tel: +98.51572223028, Email: nargesbahri@yahoo.com

Received: December 09, 2015, Accepted: January 26, 2016, Published: March 2016

iThenticate screening: January 26, 2016, English editing: February 18, 2016, Quality control: March 02, 2016

(C) 2016 The Authors. This is an open access article under the terms of the Creative Commons Attribution-NonCommercialNoDerivs License, which permits use and distribution in any medium, provided the original work is properly cited, the use is non-commercial and no modifications or adaptations are made. 
infections caused by hospitalization (3). In order to prevent medical errors, it is important to know why they occur and to identify their causes. In the year 2000, Professor James Reason introduced a new approach in solving the problems caused by human errors in organizations, i.e., the system approach as opposed to the usual person approach (4). The person approach focuses on errors caused by individuals and blames them for their errors due to forgetfulness, inattention, or moral weakness. However, the system approach emphasizes the working conditions of the individual and tries to develop effective preventive measures to avert errors or mitigate their harmful effects. In the system approach, organizations predict the worst conditions and possibilities and prepare themselves to face them. People in these organizations have realized that they should learn from their mistakes and use them to their own advantage (4). Following the introduction of the system approach into healthcare performance, the use of different methods of risk management in order to reduce medical errors and increase the safety of patients in different fields and treatment areas has become widespread (5-8). According to the statistics presented by the National Center for Patient Safety, after the implementation of risk assessment programs, the number of medical errors decreased from 3,643 to 2,412 from 2008 to 2009 (9). One of the risk management methods is healthcare failure modes and effects analysis (HFMEA), which is a systematic and proactive method to detect and prevent medical errors (5). Previous studies have used this method to reduce Newborn Intensive Care Unit (NICU) lineassociated bloodstream infections (5) and the probability of neurological site infections (6). Using Entonox as a method to decrease labor pain is one of the regular care procedures in modern midwifery $(10,11)$, and, currently, it is considered the most common analgesia method during labor in Europe (12). Entonox is a mixture of nitrous oxide and oxygen in equal portions, and it is kept in special cylinders. Since the1980s, it has been used by mouthpieces, alone or as a supplementary method in general anesthesia (13). The fact that this analgesic can be self-administered makes it easy to use by women in labor. Moreover, due to its low solubility, it has a rapid onset and provides relief in about 30-50 seconds $(14,15)$. Although Entonox has no serious side-effects for the mother or her fetus $(16)$, some unpleasant symptoms have been reported, including dizziness, lightheadedness, nausea, vomiting, drowsiness, and numbness in the fingers $(13,17)$. In normal conditions, these side-effects are not considered serious problems, but they could cause complications during labor. For example, dizziness and drowsiness during labor may cause a woman to fall, or they may cause problems in the second stage of labor, e.g., inhibiting the pushing maneuver and prolonging the second stage. A systematic review indicated that these side-effects are related to the amount of nitrous oxide used and the period of time it is used (12); thus, we can decrease the side-effects by controlling the amount and duration of its administration. Another hazard of using Entonox is its emission into the air, which can lead to similar side-effects in the hospital staff (13). Some studies have even reported a positive relationship between occupational exposure to anesthetic gases, such as nitrous oxide, and Parkinson's disease (18). However, in a narrative review, Rooks reported that, when nitrous oxide is appropriately controlled, the occupational exposures are less than the standard set by the National Institute for Occupational Safety (12). Given the importance of using Entonox for pain relief during childbirth, the safety of this process and the reduction of medical errors in using it will lead to its widespread use to control labor pain. This might be an effective factor in decreasing the rate of Csections, increasing maternal satisfaction, and decreasing the discomfort associated with the birth experience. Therefore, the present study was conducted to assess and detect the hazards of this process using the HFMEA approach.

\section{Material and Methods}

\subsection{Research design and setting}

This study is a mixed-method study (qualitative action research and quantitative descriptive cross-sectional), and it was conducted from September 2013 to April 2014 in the maternity ward at Hefdahe Shahrivar Hospital in Mashhad, Iran. The hospital has 137 staffed beds and includes inpatient wards, a specialized clinic, and a laboratory unit. It is the only hospital in Mashhad that belongs to the Social Security Organization, and it has a maternity ward with 12 staffed beds. Approval of this study was obtained through the International Review Board.

\subsection{Data Collection}

Data gathering was done through focus groups, individual interviews, observation, and brainstorming. The validity of this study was controlled by the consensus of team members at the end of each phase. The phases of this study were conducted based on the five steps of HFMEA methodology determined by the VA National Center for Patient Safety (19), although some changes were made due to specific conditions. The steps conducted are the following: 2.2.1. Step 1- Selecting the high-risk process: By using specialists' and experts' views in the hospital and also by examining the unintended events reported form the maternity ward to the Hospital's Office of Clinical Governance, the process of using Entonox for pain relief during labor was chosen as the research sample for analysis. 
2.2.2. Step 2- Assembling the team: At this stage, 11 specialists became members of the HFMEA team, including a risk assessment manager as the team leader; a $\mathrm{PhD}$ holder in healthcare management and two Ph.D. candidates in reproductive health as consultants; an $\mathrm{OB} / \mathrm{GYN}$, the head of the maternity ward, an anesthesiologist, an anesthesiologist's assistant, a midwife, two authorities, one in charge of hospital facilities and the other responsible for providing services.

2.2.3. Step 3-Graphically describing the process: The process and its sub-processes were drawn as a diagram (by Visio software) through observation and individual interviews. The diagram was verified and confirmed by the team members in a discussion session.

2.2.4. Step 4- Hazard analysis: This step consisted of four phases:

1) Phase 1: Detecting the potential failure modes: They were detected through individual interviews and a group discussion. Then, they were classified based on the "Nursing Error Management Council" model [20] into care process, communication, administrative and knowledge, and skill error types.

2) Phase 2: Calculating the hazard score: This score was obtained through a priority matrix (by multiplying the two factors of severity and probability), and it was recorded on the HFMEA worksheet. The errors were grouped according to their hazard score into four intervention levels, i.e., emergency, urgency, programming, and monitoring [21] (Table1).

3) Phase 3: Drawing the decision tree: At this stage, prioritized errors (with a hazard score of 8 and higher) were transferred to the decision tree and decisions were made about continuing or stopping each of the failure modes based on three items i.e., weak point, current control measures, and detectability.

4) Phase 4: In this phase, influential factors on each of the continuing failure modes on the decision tree were detected by cause-effect analysis.

2.2.5. Step 5: Actions and outcome measures, taken in two phases:

1) Phase 1: Description of action: In this phase, strategies to oppose contributing factors to each failure mode were suggested in form of acceptance, control, and elimination.

2) Phase 2: Redesigning the process: Improvement strategies for each potential cause of failure were presented in group sessions, and decisions were conducted about the practicality of the strategies in view of the organization's resources.

It should be noted that all of the information on the HFMEA worksheet was gathered after reaching consensus among the team members through interviews and debriefing sessions (five one-hour sessions after each step). Moreover, 20 hours were spent for individual interviews during the research.

Table 1. Failure mode and intervention scoring matrix

\begin{tabular}{|l|l|l|l|l|l|}
\hline Intervention level & Severity probability & Catastrophic (4) & Important (3) & Intermediate (2) & Minor (1) \\
\hline Emergency & Usual (4) & 16 & 12 & 8 & 4 \\
\hline Urgent & Sometimes (3) & 12 & 9 & 6 & 3 \\
\hline Programming & Unusual (2) & 8 & 6 & 4 & 2 \\
\hline Monitoring & Rare (1) & 4 & 3 & 2 & 1 \\
\hline
\end{tabular}

\subsection{Statistical Analysis Process}

\subsubsection{Quantitative Analysis}

For the quantitative analysis of the variables related to the failure mode analysis phase, descriptive statistics were calculated in Excel software, including frequency, percent, and mean. Also, for the quantitative analysis and determination of the probability of the failures, the sum of the team's scores was used with consideration of a coefficient for each team member. For the severity of the failures, the team members' consensus along with consideration of weight for the severity of failures was used. In the final worksheet, we calculated and documented in the final worksheet the sum of failure mode severity scores according to team members' opinions and by considering weights for the failure mode severity dimensions, and we calculated the sum of the failure mode probability scores based on the involved personnel's opinions (also with considering the coefficient for each person).

\subsubsection{Qualitative Analysis}

Content analysis was done on the data collected from the individual interviews in order to put them in the organized forms. To do so, all the interviews with the team members were transcribed, and, for the sake of understanding the transcriptions, they were read, and repetitions were omitted and the significant issues were extracted. Therefore, a 
list of all of the team members' opinions was prepared. Analysis of the data from the brainstorming, cause and effect, and problem-solving sessions was done based on the general agreement of the team members.

\subsection{Ethical Consideration}

Ethical issues were considered in the decisions that were made. All team members gave informed consent to participate in the study, and the information obtained from individual interviews remained confidential.

\section{Results}

Overall, for the 20 sub-processes listed in the six steps of the process of using Entonox for pain relief in child delivery, 52 failure modes were identified, and they are listed in Table 2.

Table 2. Frequency distribution of failure modes of the sub-processes and frequency of the failure modes in the scoring matrix

\begin{tabular}{|c|c|c|c|c|c|c|c|c|c|c|}
\hline \multirow[t]{2}{*}{ Steps in the process } & \multirow[t]{2}{*}{ Sub-processes } & \multirow[t]{2}{*}{$\begin{array}{l}\text { Frequency } \\
\text { of failure } \\
\text { modes }\end{array}$} & \multicolumn{4}{|c|}{$\begin{array}{l}\text { Frequency } \\
\text { percentage of } \\
\text { failure modes }\end{array}$} & \multicolumn{4}{|c|}{$\begin{array}{l}\text { Frequency of } \\
\text { intervention } \\
\text { levels }\end{array}$} \\
\hline & & & 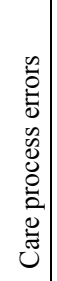 & 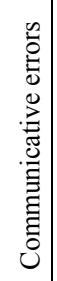 & 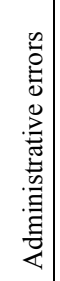 & 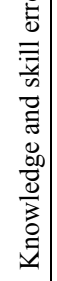 & 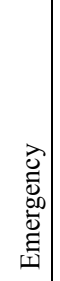 & 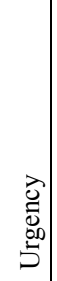 & 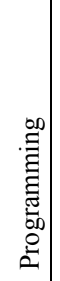 & 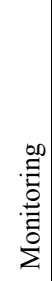 \\
\hline \multirow{2}{*}{$\begin{array}{l}\text { Order of the obstetrician } \\
\text { to start the administration } \\
\text { of Entonox }\end{array}$} & $\begin{array}{l}\text { Confirmation of the start of the active phase and ordering the } \\
\text { administration of Entonox by the doctor }\end{array}$ & 5 & 6 & 1 & 0 & 2 & 0 & 0 & 4 & 1 \\
\hline & Writing the order to administer analgesia by the obstetrician & 4 & 0 & 4 & 1 & 0 & 0 & 1 & 2 & 1 \\
\hline $\begin{array}{l}\text { Checking the doctor's } \\
\text { orders by the midwife }\end{array}$ & $\begin{array}{l}\text { Checking the doctor's order sheet by the midwife attending } \\
\text { the laboring woman }\end{array}$ & 3 & 3 & 0 & 0 & 0 & 0 & 2 & 1 & 0 \\
\hline \multirow[t]{4}{*}{$\begin{array}{l}\text { Following the } \\
\text { obstetrician's orders }\end{array}$} & $\begin{array}{l}\text { Phone calling the operation room by the midwife to ask the } \\
\text { anesthesiologist assistant to prescribe starting the use of } \\
\text { Entonox }\end{array}$ & 2 & 1 & 1 & 2 & 0 & 0 & 0 & 1 & 1 \\
\hline & $\begin{array}{l}\text { Recording the report of the phone call made to the operation } \\
\text { room by the midwife }\end{array}$ & 2 & 1 & 2 & 0 & 0 & 0 & 2 & 0 & 0 \\
\hline & $\begin{array}{l}\text { Order given by the anesthesiologist to the anesthesiologist } \\
\text { assistant to start the use of Entonox }\end{array}$ & 3 & 1 & 1 & 1 & 0 & 0 & 3 & 0 & 0 \\
\hline & $\begin{array}{l}\text { Presence of the anesthesiologist assistant in the delivery unit } \\
\text { and checking the woman's medical record }\end{array}$ & 3 & 3 & 0 & 0 & 0 & 2 & 1 & 0 & 0 \\
\hline \multirow{6}{*}{$\begin{array}{l}\text { Start of the use of } \\
\text { Entonox by the } \\
\text { anesthesiologist assistant }\end{array}$} & $\begin{array}{l}\text { Transferring the Entonox cylinder to the patient's bedside by } \\
\text { the delivery unit staff }\end{array}$ & 2 & 2 & 0 & 0 & 1 & 1 & 0 & 1 & 0 \\
\hline & $\begin{array}{l}\text { Inspection of the cylinder and manometer by the } \\
\text { anesthesiologist assistant }\end{array}$ & 2 & 2 & 0 & 2 & 0 & 0 & 0 & 2 & 0 \\
\hline & $\begin{array}{l}\text { Inspecting the color of the cylinder and gauging it with that of } \\
\text { the standard and defined cylinder }\end{array}$ & 2 & 1 & 0 & 2 & 0 & 0 & 1 & 1 & 0 \\
\hline & Instructing the mother on how to self-administer Entonox & 2 & 2 & 1 & 0 & 0 & 1 & 0 & 1 & 0 \\
\hline & $\begin{array}{l}\text { Checking how the mother uses Entonox by the } \\
\text { anesthesiologist assistant }\end{array}$ & 2 & 2 & 0 & 0 & 0 & 1 & 0 & 1 & 0 \\
\hline & $\begin{array}{l}\text { Reporting the use of Entonox on the analgesia report sheet by } \\
\text { the anesthesiologist assistant }\end{array}$ & 3 & 0 & 2 & 1 & 0 & 0 & 0 & 3 & 0 \\
\hline \multirow{2}{*}{$\begin{array}{l}\text { Supervision of the } \\
\text { woman during self- } \\
\text { administration of } \\
\text { Entonox by the midwife }\end{array}$} & Controlling and recording the administration of Entonox & 2 & 2 & 1 & 0 & 0 & 0 & 1 & 1 & 0 \\
\hline & $\begin{array}{l}\text { Monitoring and recording the woman's vital signs and } \\
\text { probable side-effects }\end{array}$ & 3 & 3 & 0 & 1 & 0 & 1 & 0 & 2 & 0 \\
\hline \multirow{5}{*}{$\begin{array}{l}\text { Cease the administration } \\
\text { of Entonox by the } \\
\text { midwife }\end{array}$} & $\begin{array}{l}\text { Internal examination of the woman and confirmation of the } \\
\text { end of the first phase of labor }\end{array}$ & 2 & 1 & 0 & 0 & 1 & 0 & 1 & 1 & 0 \\
\hline & Closing the cylinder valve and ceasing the flow of Entonox & 2 & 0 & 0 & 1 & 2 & 2 & 0 & 0 & 0 \\
\hline & $\begin{array}{l}\text { Prescription of oxygen before transferring the woman to the } \\
\text { delivery unit }\end{array}$ & 3 & 2 & 0 & 1 & 0 & 1 & 1 & 1 & 0 \\
\hline & $\begin{array}{l}\text { Recording the time of cessation of Entonox and prescribing } \\
\text { oxygen in the laboring woman's medical record }\end{array}$ & 2 & 0 & 2 & 0 & 0 & 0 & 1 & 1 & 0 \\
\hline & $\begin{array}{l}\text { Ordering to transfer the laboring woman to the delivery unit } \\
\text { by wheelchair }\end{array}$ & 3 & 1 & 0 & 1 & 1 & 2 & 0 & 1 & 0 \\
\hline
\end{tabular}


Classification of error modes according to the "nursing error management association" model showed that $59.4 \%$ of the error modes are related to the care process, $24.6 \%$ to communication, $10.14 \%$ to administrative errors, and $5.79 \%$ to knowledge and skill. Also, the interventional levels showed that $16.1 \%$ of the error modes were related to the emergency intervention, $26.9 \%$ urgent, $46.1 \%$ programmed, and 5.7\% in the monitoring area. In the next step, from the 52 detected failure modes, 25 (48.07\%) were recognized as high-risk and unacceptable (hazard score of 8 and higher) and were transferred to the decision tree. Seventeen effective factors were presented for continuing highrisk failure modes in the decision tree. Strategies suggested to oppose the contributing factors to each failure mode were presented in the forms of acceptance (3.2\%), control $(90.3 \%)$, and elimination (6.4\%). Table 3 shows the HFMEA worksheet for high-risk and unacceptable (hazard score of 8 and higher) failure modes. Improvement strategies for each failure mode were presented through "theory of innovative problem solving" by recording the error for the personnel who committed it, improving team communication, preparing practical guidelines, monitoring and continuous supervision, ensuring effective communication with patients, providing a checklist for equipment maintenance and management, matching the workload with the number of staff, process simplification and omitting unnecessary steps, fundamental promotion of the software to computerize test orders, writing and verification of a summary of the records, and making a legal requirement by the hospital director for the anesthesiologist to write the order.

Table 3. Analysis of risk assessment and management

\begin{tabular}{|c|c|c|c|c|c|c|c|c|c|c|}
\hline \multicolumn{9}{|l|}{ Hazard analysis } & \multicolumn{2}{|c|}{ Actions and outcome measures } \\
\hline \multirow[t]{2}{*}{ Failure mode } & \multirow[t]{2}{*}{ Potential causes } & \multicolumn{3}{|c|}{ Scoring } & \multicolumn{3}{|c|}{$\begin{array}{l}\text { Analysis of } \\
\text { the decision } \\
\text { tree }\end{array}$} & \multirow{2}{*}{ 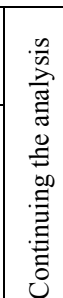 } & \multirow[b]{2}{*}{ 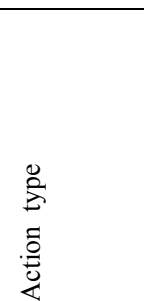 } & \multirow[t]{2}{*}{$\begin{array}{l}\text { Recommended actions or } \\
\text { reasons for stopping the analysis }\end{array}$} \\
\hline & & 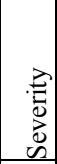 & $\begin{array}{l}: ? \\
:= \\
0 \\
0 \\
0 \\
0 \\
0\end{array}$ & 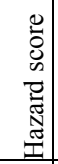 & 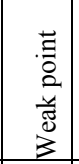 & 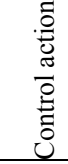 & 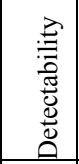 & & & \\
\hline $\begin{array}{l}\text { Incomplete recording of orders on the } \\
\text { doctor's order sheet }\end{array}$ & & 3 & 3 & 9 & No & $\rightarrow$ & $\rightarrow$ & No & Control & $\begin{array}{l}\text { Recording the error for the } \\
\text { personnel who committed it }\end{array}$ \\
\hline $\begin{array}{l}\text { Not checking the doctor's order sheet } \\
\text { by the midwife }\end{array}$ & & 3 & 3 & 9 & No & $\rightarrow$ & $\rightarrow$ & No & Control & $\begin{array}{l}\text { Recording the error for the personnel } \\
\text { who committed it }\end{array}$ \\
\hline \multirow{3}{*}{$\begin{array}{l}\text { Delay in checking the doctor's order } \\
\text { sheet by the midwife }\end{array}$} & $\rightarrow$ & 3 & 3 & 9 & $\rightarrow$ & No & No & Yes & Elimination & \\
\hline & Crowdedness of the ward & 3 & 3 & 9 & $\rightarrow$ & No & No & Yes & Control & \multirow{2}{*}{$\begin{array}{l}\text { Monitoring each woman from the } \\
\text { beginning of her hospitalization, } \\
\text { during labor and after child birth, in } \\
\text { other words, individual controlling, } \\
\text { Recording the required attempts } \\
\text { done immediately after performing } \\
\text { them in the patient's medical record } \\
\text { by the midwife herself (not the } \\
\text { student or the instructor) }\end{array}$} \\
\hline & Shortage of midwives & 2 & 3 & 6 & No & $\rightarrow$ & $\rightarrow$ & No & Control & \\
\hline $\begin{array}{l}\text { Not recording the phone call report on } \\
\text { the nursing report sheet }\end{array}$ & & 3 & 3 & 9 & No & & & No & Control & $\begin{array}{l}\text { Recording the error for the personnel } \\
\text { who committed it }\end{array}$ \\
\hline $\begin{array}{l}\text { Wrong recording of the hour or date of } \\
\text { phone call on the nursing report sheet }\end{array}$ & & 3 & 3 & 9 & No & $\rightarrow$ & $\rightarrow$ & No & Control & $\begin{array}{l}\text { Recording the error for the personnel } \\
\text { who committed it }\end{array}$ \\
\hline $\begin{array}{l}\text { Absence of the anesthesiologist at the } \\
\text { mother's bedside and no confirmation } \\
\text { of the indications for use of Entonox }\end{array}$ & & 3 & 3 & 9 & No & $\rightarrow$ & $\rightarrow$ & No & Control & $\begin{array}{l}\text { Making presence of the } \\
\text { anesthesiologist at the patient's } \\
\text { bedside a legal requirement by the } \\
\text { hospital director }\end{array}$ \\
\hline \multirow{3}{*}{$\begin{array}{l}\text { Absence of the anesthesiologist in the } \\
\text { operation room and order given by } \\
\text { phone call }\end{array}$} & $\longrightarrow$ & 3 & 3 & 9 & $\rightarrow$ & No & No & Yes & Elimination & \multirow{3}{*}{$\begin{array}{l}\text { Making presence of the } \\
\text { anesthesiologist at the patient's } \\
\text { bedside a legal requirement by the } \\
\text { hospital director, Recording the error } \\
\text { made by the anesthesiologist } \\
\text { assistant who followed the call order }\end{array}$} \\
\hline & $\begin{array}{l}\text { The anesthesiologist's lack of } \\
\text { awareness }\end{array}$ & 3 & 2 & 6 & $\rightarrow$ & No & No & Yes & Elimination & \\
\hline & $\begin{array}{l}\text { lack of team work between the } \\
\text { operation room staff and the } \\
\text { anesthesiologist }\end{array}$ & 3 & 3 & 9 & & No & No & Yes & Control & \\
\hline $\begin{array}{l}\text { Orally giving order without recording } \\
\text { it in the patient's medical record, } \\
\text { despite the presence of the } \\
\text { anesthesiologist in the operation room }\end{array}$ & & 3 & 3 & 9 & $\underset{\rightarrow}{\mathrm{No}}$ & $\rightarrow$ & $\rightarrow$ & No & Control & $\begin{array}{l}\text { Making legal requirement by the } \\
\text { hospital director for the } \\
\text { anesthesiologist to write the order }\end{array}$ \\
\hline $\begin{array}{l}\text { Delay in the arrival of the } \\
\text { anesthesiologist's assistant at the }\end{array}$ & & 3 & 3 & 9 & Yes & Yes & $\rightarrow$ & No & Control & $\begin{array}{l}\text { Recording the time of the call made } \\
\text { by the midwife to the anesthesiologist }\end{array}$ \\
\hline
\end{tabular}




\begin{tabular}{|c|c|c|c|c|c|c|c|c|c|c|}
\hline delivery unit & & & & & & & & & & $\begin{array}{l}\text { assistant in the woman's medical } \\
\text { record, which based on the regulation } \\
\text { of the ward if it takes more than } 15 \\
\text { minutes for the anesthesiologist } \\
\text { assistant to get to the delivery unit it } \\
\text { should be reported to the head of the } \\
\text { operation room. }\end{array}$ \\
\hline $\begin{array}{l}\text { Checking the wrong medical record by } \\
\text { the anesthesiologist assistant }\end{array}$ & & 3 & 4 & 12 & No & $\rightarrow$ & $\rightarrow$ & No & Control & $\begin{array}{l}\text { Giving oral note to the } \\
\text { anesthesiologist assistant who } \\
\text { committed the error and recording it } \\
\text { in his/her personnel record in case of } \\
\text { repetition of error }\end{array}$ \\
\hline $\begin{array}{l}\text { Error in identifying the parturient and } \\
\text { not corresponding the medical record } \\
\text { to the right parturient }\end{array}$ & & 3 & 4 & 12 & Yes & Yes & $\rightarrow$ & No & Control & $\begin{array}{l}\text { Presence of both midwife and } \\
\text { anesthesiologist's assistant at the } \\
\text { mother's bedside and double } \\
\text { monitoring of medical record } \\
\text { correspondence to patient, Codifying } \\
\text { a policy for identifying patients and } \\
\text { informing the staff about it }\end{array}$ \\
\hline $\begin{array}{l}\text { Lack of carrier with an appropriate } \\
\text { chain }\end{array}$ & & 4 & 4 & 16 & Yes & Yes & $\rightarrow$ & No & Control & $\begin{array}{l}\text { Using an appropriate carrier with a } \\
\text { good chain to keep capsule strongly }\end{array}$ \\
\hline \multirow{3}{*}{$\begin{array}{l}\text { Lack of correspondence between the } \\
\text { color of the cylinder and the color of } \\
\text { the manometer }\end{array}$} & & 2 & 4 & 8 & $\rightarrow$ & No & No & Yes & & \multirow{3}{*}{$\begin{array}{l}\text { Attaching a warning label to the } \\
\text { manometer reminding about the } \\
\text { necessity of color correspondence } \\
\text { between the manometer and the } \\
\text { cylinder, Daily checking of the } \\
\text { cylinders and their dates by Technical } \\
\text { Services, Daily controlling and } \\
\text { corresponding of cylinders with the } \\
\text { manometer, paying attention to the } \\
\text { color of the cylinder and the } \\
\text { manometer by the head of the shift } \\
\text { and signing the report sheet }\end{array}$} \\
\hline & Crowdedness of the ward & 3 & 3 & 9 & $\rightarrow$ & No & No & Yes & Control & \\
\hline & $\begin{array}{l}\text { Inattentiveness of staff and not } \\
\text { considering the issue } \\
\text { important }\end{array}$ & 3 & 3 & 9 & $\rightarrow$ & No & No & Yes & Control & \\
\hline \multirow{3}{*}{$\begin{array}{l}\text { Ineffectiveness of instruction to } \\
\text { parturient about using Entonox }\end{array}$} & $\longrightarrow$ & 4 & 3 & 12 & $\rightarrow$ & No & No & Yes & Acceptance & \multirow{3}{*}{$\begin{array}{l}\text { Teaching the correct way to use } \\
\text { Entonox in childbirth education } \\
\text { classes, providing certification for } \\
\text { the use of Entonox during labor to } \\
\text { women who attend the classes and not } \\
\text { permitting the use of Entonox } \\
\text { otherwise }\end{array}$} \\
\hline & $\begin{array}{l}\text { Inattention of the laboring } \\
\text { woman to the instruction } \\
\text { provided due to severe labor } \\
\text { pain }\end{array}$ & 3 & 4 & 12 & $\rightarrow$ & No & No & Yes & Acceptance & \\
\hline & $\begin{array}{l}\text { Lack of effective } \\
\text { communication between the } \\
\text { laboring woman and } \\
\text { healthcare providers }\end{array}$ & 2 & 2 & 4 & $\rightarrow$ & No & No & Yes & Control & \\
\hline \multirow{3}{*}{$\begin{array}{l}\text { Absence of the anesthesiologist } \\
\text { assistant at the woman's bedside } \\
\text { during the administration of Entonox }\end{array}$} & $\longrightarrow$ & 4 & 3 & 12 & $\rightarrow$ & No & No & Yes & & \multirow{3}{*}{$\begin{array}{l}\text { Making legal requirement by the } \\
\text { hospital director about compulsory } \\
\text { presence of the anesthesiologist } \\
\text { assistant during the administration of } \\
\text { Entonox, Making legal requirement } \\
\text { about not using Entonox when the } \\
\text { anesthesiologist assistant is not } \\
\text { present, Recording the error made by } \\
\text { the midwife or anesthesiologist } \\
\text { assistant, Holding briefing sessions } \\
\text { for the anesthesiologist assistants } \\
\text { upon starting work in the hospital }\end{array}$} \\
\hline & $\begin{array}{l}\text { Shortage of anesthesiologist } \\
\text { assistants in the operation } \\
\text { room }\end{array}$ & 3 & 3 & 9 & $\rightarrow$ & No & No & Yes & Control & \\
\hline & $\begin{array}{l}\text { Carelessness and } \\
\text { inattentiveness of } \\
\text { anesthesiologist assistant }\end{array}$ & 3 & 2 & 6 & $\rightarrow$ & No & No & Yes & Elimination & \\
\hline $\begin{array}{l}\text { Not recording the start of the use of } \\
\text { Entonox on the nursing report sheet of } \\
\text { the delivery unit }\end{array}$ & & 3 & 3 & 9 & Yes & Yes & $\rightarrow$ & No & Control & $\begin{array}{l}\text { Devoting one partograph sheet to } \\
\text { each mother and hourly recording of } \\
\text { vital signs and probable side-effects } \\
\text { of Entonox on the partograph sheet by } \\
\text { the midwife }\end{array}$ \\
\hline $\begin{array}{l}\text { The manometer not working properly } \\
\text { or not calibrated }\end{array}$ & & 3 & 4 & 12 & Yes & Yes & $\rightarrow$ & No & Control & $\begin{array}{l}\text { Controlling by the head of the shift at } \\
\text { the beginning of the shift, Reporting } \\
\text { the problem with the manometer to } \\
\text { the person in charge of medical } \\
\text { facilities, Regular calibration of } \\
\text { medical equipment by a specialist }\end{array}$ \\
\hline \multirow{3}{*}{$\begin{array}{l}\text { Negligence and delay in performing } \\
\text { the internal examination and overuse } \\
\text { of Entonox by the woman }\end{array}$} & $\Rightarrow$ & 2 & 4 & 8 & $\rightarrow$ & No & No & Yes & & \multirow{3}{*}{$\begin{array}{l}\text { Sticking the report sheet concerning } \\
\text { the time Entonox use was started for } \\
\text { the woman to the whiteboard above } \\
\text { the woman's bed, with the recorded }\end{array}$} \\
\hline & Crowdedness of the ward & 3 & 3 & 9 & $\rightarrow$ & No & No & Yes & Control & \\
\hline & Not enough importance given & 3 & 4 & 12 & $\rightarrow$ & No & No & Yes & Control & \\
\hline
\end{tabular}




\begin{tabular}{|c|c|c|c|c|c|c|c|c|c|c|}
\hline & $\begin{array}{l}\text { to the issue by midwives due } \\
\text { to the harmlessness of } \\
\text { Entonox }\end{array}$ & & & & & & & & & $\begin{array}{l}\text { time highlighted in red, Making } \\
\text { obligatory hourly examination of the } \\
\text { woman by the midwife }\end{array}$ \\
\hline Inattention to ceasing the flow of gas & & 4 & 3 & 12 & Yes & Yes & $\rightarrow$ & No & Control & $\begin{array}{l}\text { Controlling the cessation of Entonox } \\
\text { by the midwife }\end{array}$ \\
\hline \multirow[t]{2}{*}{ Entonox emitted in the delivery unit } & & 4 & 3 & 12 & & No & No & Yes & & \multirow{2}{*}{$\begin{array}{l}\text { Weekly control of the cylinders by } \\
\text { Technical Services, Writing a report } \\
\text { on the technical control of the } \\
\text { cylinders by the controller }\end{array}$} \\
\hline & $\begin{array}{l}\text { No monitoring by Technical } \\
\text { Services }\end{array}$ & 2 & 3 & 6 & & No & No & Yes & Control & \\
\hline \multirow{3}{*}{$\begin{array}{l}\text { Delay in identifying the second phase } \\
\text { of labor and lack of enough time to } \\
\text { prescribe oxygen }\end{array}$} & & 4 & 2 & 8 & $\rightarrow$ & No & No & Yes & & \multirow{3}{*}{$\begin{array}{l}\text { Making obligatory the use of oxygen } \\
\text { for mothers using Entonox during } \\
\text { labor, Individual monitoring (one } \\
\text { midwife for each mother) }\end{array}$} \\
\hline & Inattentiveness of the staff & & & & & & & & Control & \\
\hline & Crowdedness of the ward & 3 & 3 & 9 & $\rightarrow$ & No & No & Yes & Control & \\
\hline $\begin{array}{l}\text { Wrong recording of the time } \\
\text { inhalation was ceased }\end{array}$ & & 4 & 2 & 8 & & No & Yes & No & Control & $\begin{array}{l}\text { Observation of the written reports by } \\
\text { the head of the shift }\end{array}$ \\
\hline \multirow{3}{*}{$\begin{array}{l}\text { Delay in transferring the woman in } \\
\text { labor }\end{array}$} & & 4 & 3 & 12 & $\rightarrow$ & No & No & Yes & & \multirow{3}{*}{$\begin{array}{l}\text { Individual monitoring (one midwife } \\
\text { for each mother, Increasing the } \\
\text { number of personnel on the ward }\end{array}$} \\
\hline & Staff shortage & 2 & 3 & 6 & No & $\rightarrow$ & $\rightarrow$ & No & Control & \\
\hline & Crowded ward & 3 & 3 & 9 & $\rightarrow$ & No & No & Yes & Control & \\
\hline
\end{tabular}

\section{Discussion}

In this study, HFMEA, as a proactive method, was used to detect the important errors in using Entonox, and corrective actions were recommended for each error. Overall, 52 failure modes were identified. According to the Nursing Errors relating to Clinical Management (NECM) taxonomy, $48.5 \%$ of these errors fell into the care process, $22.05 \%$ belonged to communication, $19.1 \%$ were associated with the administrative process, and $10.2 \%$ were knowledge and skill type. The results of this study are similar to those of the study conducted by the Nursing Error Management Council, in which the percentages of errors were reported as follows: care processes (66\%), communication (22\%), administrative processes $(6 \%)$, and knowledge $(5 \%)(20-23)$. However, in the abovementioned study, errors were examined retrospectively, and, from this perspective, it differs from our study, which examined errors proactively. In another similar study conducted by Khani et al. in 2014, similar results also were obtained (21). The findings showed that $59.4 \%$ of errors belonged to care processes, $24.6 \%$ to communication, $10.14 \%$ to administrative processes, and $5.79 \%$ to knowledge and skill. In the present study, from the 52 failure modes identified, 25 of them $(48.07 \%)$ were detected as high-risk and unacceptable (with a hazard score of 8 or higher). We will examine some instances of high-risk failure modes in the following parts. One of the findings of the present study indicated that the ineffectiveness of instruction on the use of Entonox for women during labor, with a hazard score of 12, was one of the continuing failure modes according to the decision tree. Based on the views of the members of the research team, communication and patient factors (severe labor pain) were the main contributing causes of this failure mode. In this respect, Mashoof et al. and Aghabarary et al. also mentioned the lack of patient involvement in the care process as a predisposing factor in nursing errors $(24,25)$. Also, anxiety, worry, and physical discomfort of the patient have been reported as main barriers to proper nurse-patient interactions (25). The results of the latter study are in line with our findings, i.e., the midwife's failure in communicating with the woman in labor and following that ineffectiveness of instruction to the woman due to severe pain during labor. Gas emissions in the labor and delivery units, with a hazard score of 12 , were one of the failure modes in the study, which the research team attributed to team factors. In some studies, the emission of Entonox into the environment was one of the hazards attributed to this gas. For example, it has been claimed that Entonox can have the same sideeffects on the hospital staff that it has on women in labor (13); however, the important point is that, with close and periodic control of Entonox cylinders, its emission into the environment can be prevented. Delay in transferring a woman in labor to the delivery unit was another high-risk failure mode in this study. The experts and members of the research team attributed staff shortages and the high number of women in labor as the main causes. Previous studies have indicated that one of the highly important factors in error occurrence is heavy workload. For instance, Rahimian Boogar et al. reported a significant relationship between heavy workload and occurrence of nursing errors (26). Joolaee et al. and Keller also reported that the job conditions of nurses, extended work shifts, and heavy workloads raise the probability of nursing errors, thereby endangering patients $(27,28)$. Likewise, Montgomery's study indicated that heavy workload and fatigue have a significant role in healthcare providers' errors (29).

Another high-risk failure mode in this research was the absence of an anesthesiologist assistant at the mother's bedside with a hazard score of 12 , which the team members attributed to staff shortages and negligence in performing duties due to inadequate training. Some other earlier studies also have noted staff shortages as one of the 
most significant causes of nursing errors. As an example, in a study conducted by Mashoof et al., factors predisposing nursing errors in intensive care units were investigated, and the low ratio of nurses to patients and the lack of sufficient time for monitoring patients were reported as the main causes of nursing errors (24). In that study, the lack of a proper staff training system and unfamiliarity with professional rules and regulations were some other predisposing factors that were mentioned. Baghaei et al. also showed similar results, by mentioning the lack of educational facilities in the work environment and the indifference of authorities to staff training as some of the factors leading to nursing errors (30). In this research, all failure modes were classified into one of the following intervention levels based on their hazard score: emergency, urgency, programming, and monitoring. The most to least frequent errors were at programming, urgency, emergency, and monitoring levels, respectively. In Bonfant et al.'s study, out of the 93 errors in the dialysis unit, no errors existed at the emergency intervention level; $9.6 \%$ of errors were at the urgent level, $38.7 \%$ at the programming level, and $51.6 \%$ at the monitoring level (22). The reason for the difference in the results of the present study with those of Bonfant et al. study can be attributed to the different research environments. As mentioned before, results of risk assessment and detection of errors in each organization are only generalizable to that place and cannot be compared with those of other environments.

\section{Study strength and limitation}

The most significant strength of the present study is its proactive approach in identifying errors and their risks, for the reason that in most studies, the classification of medical errors has been through a retrospective approach (31, 32). One of the advantages of this research compared to similar studies conducted by the HFMEA technique was that the severity and probability of errors were determined individually and independently. Independent scoring of team members has the advantage of wearing off the halo effect (cognitive bias caused by an observers' overall impression of a person or situation), which exists in group discussions (32). Another strong point of this study was the classification of errors into intervention levels of emergency, urgency, programming, and monitoring. Considering the shortage of resources in organizations, this taxonomy makes it possible to perform corrective actions and to focus on reduction of error risks based on their intervention levels (30). One of the limitations of this study, and of all studies that use the HFMEA approach, is that showing a decrease in the probability of occurrence of adverse events is difficult after conducting interventions; thus, one cannot prove the improvement of patients' safety or do cost-benefit analysis by using HFMEA programs (28). Another limitation is the non-generalizability of the results, since determining high-risk failure modes in each institute depends on its own work and environmental conditions.

\section{Conclusions}

The results of the study showed that some actions can improve the process of using Entonox for labor pain, including: the necessity of individual monitoring during stages of labor, close supervision by the midwife on the process of using Entonox by the woman in labor, the necessity of the presence of the anesthesiologist at the woman's bedside, and confirming the indications for use of Entonox, obligation of the constant presence of the anesthesiologist assistant at the laboring woman's bedside during the process of using Entonox, careful supervision by the person in charge of the medical facilities and the head of the maternity ward on the safety of Entonox cylinders and gas leakage, and closely monitoring the safety of the gas cylinder guards.

\section{Acknowledgments:}

This project is an assignment of a Ph.D. course and there was no financial support for it. The researchers thank the members of the assessment team, who were Mrs. Malekpoure, Dr. Asgharian, Dr. Mirshahpanah, and Mrs. Behnam.

\section{Conflict of Interest:}

There is no conflict of interest to be declared.

\section{Authors' contributions:}

All authors contributed to this project and article equally. All authors read and approved the final manuscript.

\section{References}

1) Garrouste-Orgeas M, Philippart F, Bruel C, Max A, Lau N, Misset B. Overview of medical errors and adverse events. Ann Intensive Care. 2012; 2(1): 2. doi: 10.1186/2110-5820-2-2.

2) Institute of medicine. To Err is Human: Building a Safer Health System. November 1999, Available from: http://www.iom.edu/ /media/Files/Report\%20Files/1999/To-Err-is Human/To\%20Err\%20is\%20Human\%201999\%20\%20report\%20brief.pdf 
3) Carolyn M, Clancy M. Ten Years After To Err Is Human. Am J Med Qual. 2009; 24(6): 525-8. doi: 10.1177/1062860609349728.

4) Reason J. Human error: models and management. BMJ. 2000; 320: 768-70. PMID: 10720363, PMCID: PMC1117770.

5) Chandonnet CJ, Kahlon PS, Rachh P, Degrazia M, Dewitt EC, Flaherty KA, et.al. Health care failure mode and effect analysis to reduce NICU line-associated bloodstream infections. Pediatrics. 2013; 131(6): e19619. doi: 10.1542/peds.2012-3293, PMID: 23690523.

6) Hover AR, Sistrunk WW, Cavagnol RM, Scarrow A, Finley PJ, Kroencke AD, et al. Effectiveness and Cost of Failure Mode and Effects Analysis Methodology to Reduce Neurosurgical Site Infections. Am J Med Qual. 2014; 29(6): 517-21. doi: 10.1177/1062860613505680, PMID: 24101683.

7) Nielsen DS, Dieckmann P, Mohr M, Mitchell AU, Østergaard D. Augmenting health care failure modes and effects analysis with simulation. Simul Healthc. 2014; 9(1): 48-55. doi: 10.1097/SIH.0b013e3182a3defd, PMID: 24492339.

8) Kolich M. Using Failure Mode and Effects Analysis to design a comfortable automotive driver seat. Appl Ergon. 2014; 45(4): 1087-96. doi: 10.1016/j.apergo.2014.01.007, PMID: 24529532.

9) Eadie A. Medical error reporting should it be mandatory in Scotland? J Forensic Leg Med. 2012; 19(7): 437-41. doi: 10.1016/j.jflm.2012.04.007.

10) Varposhti MR, Ahmadi N, Masoodifar M, Shahshahan Z, Tabatabaie MH. Comparison of remifentanil: Entonox with Entonox alone in labor analgesia. Adv Biomed Res. 2013; 2: 87. doi: 10.4103/22779175.122511 .

11) Talebi H, Nourozi A, Jamilian M, Baharfar N, Eghtesadi-Araghi P. Entonox for labor pain: A randomized placebo controlled trial. Pak J Biol Sci. 2009; 12: 1217-21. doi: 10.3923/pjbs.2009.1217.1221, PMID: 19943458.

12) Rooks Jp. Safety and risks of nitrous oxide labor analgesia: a review. J Midwifery Womens Health. 2011; 56(6): 557-65. doi: 10.1111/j.1542-2011.2011.00122.x, PMID: 22060215.

13) King TL, Wong CA. Nitrous oxide for labor pain: is it a laughing matter? Anesth Analg. 2014; 118(1): 124. doi: 10.1213/ANE.0000000000000017, PMID: 24356155.

14) Stewart RD, Paris PM, Stoy WA, Cannon G. Patient-controlled inhalational analgesia in prehospital care: a study of side-effects and feasibility. Crit Care Med. 1983; 11(11): 851-5. doi: 10.1097/00003246198311000-00002, PMID: 6354585.

15) Kan AS, Caves N, Wong SY, Ng EH, Ho PC. A double-blind, randomized controlled trial on the use of a 50:50 mixture of nitrous oxide/oxygen in pain relief during suction evacuation for the first trimester pregnancy termination. Hum Reprod. 2006; 21: 2606-11. doi: 10.1093/humrep/del234, PMID: 16790607.

16) Volmanen P, Akural E, Raudaskoski T, Ohtonen P, Alahuhta S. Comparison of remifentanil and nitrous oxide in labour analgesia. Acta Anaesthesiol Scand. 2005; 49(4): 453-8. doi: 10.1111/j.13996576.2005.00639.x, PMID: 15777291.

17) Pasha H, Basirat Z, Hajahmadi M, Bakhtiari A, Faramarzi M, Salmalian H. Maternal expectations and experiences of labor analgesia with nitrous oxide. Iran Red Crescent Med J. 2012; 14(12): 792-7. doi: 10.5812/ircmj.3470. PMCID: PMC3587869.

18) Likis FE, Andrews JC, Collins MR, Lewis RM, Seroogy JJ, Starr SA, et al. Nitrous oxide for the management of labor pain: a systematic review. Anesth Analg. 2014; 118(1): 153-67. doi: 10.1213/ANE.0b013e3182a7f73c, PMID: 24356165.

19) Mastrangelo G, Comiati V, dell'Aquila M, Zamprogno E. Exposure to anesthetic gases and Parkinson's disease: a case report. BMC Neurol. 2013; 13: 194. doi: 10.1186/1471-2377-13-194, PMID: 24321326, PMCID: PMC3878925.

20) DeRosier J, Stalhandske E, Bagian JP, Nudell T. Using health care Failure Mode and Effect Analysis: the VA National Center for Patient Safety's prospective risk analysis system. Jt Comm J Qual Improv. 2002; 28(5): 248-67, 209. PMID: 12053459.

21) Khani-Jazani R, Molavi-Taleghani Y, Seyedin H, Vafaee-Najar A, Ebrahimipour H, Pourtaleb A. Risk Assessment of Drug Management Process in Women Surgery Department of Qaem Educational Hospital (QEH) Using HFMEA Method (2013). Iran J Pharm Res. 2015; 14(2): 495-504. PMID: 25901157, PMCID: PMC4403066

22) Bonfant G, Belfanti P, Paternoster G, Gabrielli D, Gaiter AM, Manes M, et al. Clinical risk analysis with failure mode and effect analysis (FMEA) model in a dialysis unit. J Nephrol. 2010; 23(1): 111-8. PMID: 20091494. 
23) Tran Dt, Janson M. Classifying nursing errors in clinical management within an Australian hospital. Int Nurs Rev. 2010; 57(4): 454-62. doi: 10.1111/j.1466-7657.2010.00846.x, PMID: 21050197.

24) Mashoof S, Esmaeilpour S, Sheighi AA, Naeini MK. The Study of Factors Predisposing Nursing Errors in Intensive Care Units from Selected Hospitals' Nurses' Perspectives in Tabriz in 2012. Iranian Journal of Health \& Care. 2013; 15(1\&2): 16-25.

25) Aghabarary M, Mohammadi E, Varvani-Farahani A. Barriers to Application of Communicative Skills by Nurses in Nurse-Patient Interaction: Nurses and Patients' Perspective. IJN. 2009; 22(61): 19-31.

26) Rahimian Boogar I, Ghodrati Mirkouhi M. Role of workload, sleep, mental health and individual factors in occurrence of nursing errors. J Gorgan Uni Med Sci. 2013; 15(3): 103-9.

27) Joolaee S, Hajibabaee F, Peyrovi H, Haghani H, Bahrani N. The relationship between incidence and report of medication errors and working conditions. Int NursRev. 2011; 58(1): 37-44. doi: 10.1111/j.14667657.2010.00872.x, PMID: 21281291.

28) Keller SM. Effects of extended work shifts and shift work on patient safety, productivity and employee health. AAOHN J. 2009; 57(12): 497-502. doi: 10.3928/08910162-20091124-05, PMID: 20043622.

29) Montgomery VL. Effect of fatigue, workload and environment on patient safety in the pediatric intensive care unit. Pediatr Crit Care Med. 2007; 8(2Suppl): S11-6. doi: 10.1097/01.PCC.0000257735.49562.8F, PMID: 17496827.

30) Baghaei R,Naderi $Y$, Khalkhali $\mathrm{H}$. Evaluation of predisposing factors in nursing error in critical care units of Urmia University of Medical Sciences Hospitals. Journal of Urmia Nursing and Midwifery Faculty. 2012; 10(3): 312-20.

31) Steele CF, Rubin G, Fraser S. Error classification in community optometric practice - a pilot project. Ophthalmic \& physiological optics. Ophthalmic Physiol Opt. 2006; 26(1): 106-10. doi: 10.1111/j.14751313.2005.00360.x, PMID: 16390489.

32) McKay J, Bradley N, Lough M, Bowie P. A review of significant events analysed in general practice: implications for the quality and safety of patient care. BMC Fam Pract. 2009; 10: 61. doi: 10.1186/14712296-10-61, PMID: 19723325, PMCID: PMC2744665.

33) Anderson O, Brodie A, Vincent CA, Hanna GB. A systematic proactive risk assessment of hazards in surgical wards: a quantitative study. Ann Surg. 2012; 255(6): 1086-92. doi: 10.1097/SLA.0b013e31824f5f36, PMID: 22504280. 